\title{
Homocysteine levels in septic shock
}

\author{
L Mateu Campos', L Galarza Barrachina ${ }^{1 *}$, M Arlandis Tomas', F Sanchez Morán², A Belenguer Muncharaz ${ }^{1}$ \\ D Ferrándiz Sellés ${ }^{1}$, S Altaba Tena' ${ }^{1}$ J Torres Garcia', G Pagés Aznar ${ }^{1}$ \\ From ESICM LIVES 2015 \\ Berlin, Germany. 3-7 October 2015
}

\section{Objectives}

To assess the role of homocysteine (HCY) in sepsis, its relationship with inflammation and its possible prothrombotic effect.

\section{Methods}

Prospective cohort study of patients admitted to the Intensive Care Unit with criteria of septic shock (SCCC 2001), mechanically ventilated and requiring vasoactive drugs. Demographic variables, haemodynamics, respiratory, renal function, CRP and lactate were collected. HCY levels, coagulation factors II, VII, VIII and XII were determined at admission (T1), at 48 (T2) and 72 hours (T3), and at discharge from ICU or prior to death (T4) were analyzed.

\section{Results}

Twenty-three (12 males, 11 females), mean age 74.5 years and APACHE II $18.33 \pm 6.59$ were included. The type of admission was surgical in 11 patients and medical in 12 patients. The overall mortality was $39 \%$ (9 patients). HCY levels were higher in those patients who died and these differences were significant at $\mathrm{T} 2$, $\mathrm{T} 3$ and at the end of the study (T4) ( $<<0.005)$. Plasma HCY levels revealed a statistically significant positive correlation with plasma factor VII $(\mathrm{r}=0.35, \mathrm{p}<0.05)$ and plasma factor VIII $(\mathrm{r}=0.31, \mathrm{p}<0.05)$ at admission. Also, a statistically significant positive correlation was obtained between HCY and the cytokines IL-8, IL-10 and IL-10/ TNF-a ratio at 48 hours of the study.

\section{Conclusions}

High HCY levels in septic patients are associated with increased mortality. HCY plays a major role in septic patients due to its pro-inflammatory and pro-coagulant effect.

${ }^{1}$ Hospital General de Castellon, Castellón de la Plana, Spain

Full list of author information is available at the end of the article

\section{Authors' details}

${ }^{1}$ Hospital General de Castellon, Castellón de la Plana, Spain. ${ }^{2}$ Hospital de la Plana, Vila-real, Spain.

Published: 1 October 2015

doi:10.1186/2197-425X-3-S1-A305

Cite this article as: Mateu Campos et al: Homocysteine levels in septic shock. Intensive Care Medicine Experimental 2015 3(Suppl 1):A305.

\section{SpringerOpen $^{\odot}$}

(C) 2015 Mateu Campos et al.; This is an Open Access article distributed under the terms of the Creative Commons Attribution License (http://creativecommons.org/licenses/by/4.0), which permits unrestricted use, distribution, and reproduction in any medium, provided the original work is properly cited.
Submit your manuscript to a SpringerOpen ${ }^{\circ}$ journal and benefit from:

- Convenient online submission

- Rigorous peer review

- Immediate publication on acceptance

- Open access: articles freely available online

- High visibility within the field

- Retaining the copyright to your article

Submit your next manuscript at $>$ springeropen.com 